\title{
HEMIPLEGIA AND RETROBULBAR NEURITIS AFTER SUBARCHNOID BLOCK
}

\author{
S.V. Ghate, S.G. Kulkarni and G.S. Sarate
}

\begin{abstract}
A 25 year old man was given a subarachnoid anaesthetic for repair of hydrocele. He developed left-sided hemiplegia and retrobulbar neuritis three hours after the procedure. He recovered 45 days later after steroid therapy. There was some residual neurological deficit. The differential diagnosis is discussed.
\end{abstract}

Key Words: ANAESTHESIA, subarachnoid; Complications, Brain, hemiplegia, retrobulbar neuritis.

THE ADMINISTRATION of subarachnoid anaesthesia for pelvic and lower abdominal operations has become so common, particularly in a developing country such as India, that its safety is taken for granted. Large series have been reported without major complication ${ }^{1,2}$ yet various monographs $^{3,4}$ suggest that neurological complications are not at all uncommon. This is the report of a patient who developed hemiplegia and retrobulbar neuritis three hours after subarachnoid block.

\section{CASE RePORT}

A right handed 25 year old sedentary worker was admitted to our hospital 30th March 1980 for repair of hydrocele of six months duration. He had been in good health until the early part of 1975, when he was operated under general anaesthesia for peptic ulcer and had made an uneventful recovery. The present operation took place under subarachnoid block the day after admission.

Preoperative assessment and laboratory investigation did not reveal any abnormaiity. There was no history suggestive of diabetes, hypertension, syphilis, collagen or neurological disease, muscular weakness, convulsions, myocardial infarction, vaccination, upper respiratory tract infection. There was no family history of neurological disease.

S.V. Ghate, M.D., Lecturer in Anaesthesiology; S.G. Kulkarni, M.D., Lecturer in Medicine; G.S. Sarate, M.D., Reader in Anesthesiology, Swami Ramandand Teerth Rural Medical College, Ambajogai, Dist. Beed. Maharashtra, India.

Address Correspondence to: Dr. S.V. Ghate, Lecturer in Anaesthesiology, S.R.T.R. Medical College, Ambajogai. Dist. Beed. Maharashtra, India. Pin code No. 431517.
He was not premedicated. The subarachnoid puncture was done at the $L 2 / 3$ interspace with a 21 gauge needle and $1.5 \mathrm{ml}$ of lidocaine five per cent was injected. The intraoperative course was uneventful.

Half an hour after conclusion of the operation he experienced severe pain in the cervical region and a generalized throbbing headache, not related to posture. Three hours later focal convulsive movements were noticed followed by numbness and weakness of the left upper extremity and after six hours the left lower extremity became involved along with diminution of vision in the left eye. He remained fully conscious during this period. He was incontinent of urine but not of faeces.

On examination he was found to be febrile with temperature of $38.4^{\circ} \mathrm{C}$. The left eye was tender and the field of vision constricted. Neurologically there was hemianaesthesia below the 4th cervical dermatome, hypotonia and areflexia of the left extremities with grade II power in the left lower and none in the left upper extremity. The left plantar reflex was doubtful. Laboratory and radiological investigation were normal. Dexamethasone $4 \mathrm{mg}$ was given intramuscularly thereafter every six hours. On the fifth postoperative day there was still complete hemianaesthesia but with brisk reflexes on the left side. By the 18 th postoperative day the vision in the left eye had become reduced to finger counting at a distance of two metres. Only thirty per cent sensation was present in a patchy manner on left side. When tested the following week there was again complete hemianaesthesia with still further diminution of vision. Dexamethasone $0.5 \mathrm{ml}$ was injected into the retrobulbar space for the next two days. Vision returned to normal within these two days, and the neurological picture improved dur- 
ing the next two weeks. Steroids were tapered off. One and one half months after the operation there was grade III and IV power in upper and lower limbs respectively. Deep tendon reflexes were still brisk. Further follow up could not be done as the patient absconded from hospital.

\section{Discussion}

Hemiplegia developing within a few hours of an uneventful subarachnoid block in a young patient suggests the possibility of a pre-existing systemic disorder, such as encephalitis, meningitis, rheumatic heart disease, intracranial tumour, diabetes, syphilis, collagen disease, hypertensive encephalopathy, atherosclerosis, uraemia, multiple scelerosis, sickle cell anaemia, homocystinuria or an incidental event, as for instance cortical venous thrombosis. The patient was investigated with these possibilities in mind. All investigations were within normal limits.

The subarachnoid analgesia cannot be incriminated in this complication as the lesion was not restricted to the lower spinal level and developed within a few hours of the procedure. ${ }^{5}$ Most neurological complications after subarachnoid block follow cardiac arrest ${ }^{6}$ or severe hypotension. ${ }^{7}$ None of these occurred during operation in our patient. Hemiplegia due to transient angiospasm or a small thrombosis due to vascular disease has been reported. ${ }^{8}$ This seems to be unlikely in this young patient in the absence of a systemic disorder.

Subarachnoid analgesia can precipitate ${ }^{8.9}$ or exacerbate ${ }^{10}$ pre-existing neurological disease. Hemiplegia due to ascending myelitis progressing to encephalomyelitis has been reported. ${ }^{8}$ Restriction of the neurological lesion to one side of the body in a conscious patient with normal cerebrospinal fluid rules out this possibility in our patient. Macdonald ${ }^{8}$ and Fleiss ${ }^{9}$ have reported multiple sclerosis to be precipitated by subarachnoid block. Acute onset, a fluctuating clinical course, response to steroids, unilateral retrobulbar neuritis, and affection of more than one central nervous system struclure suggest that the neurological complications in our patient might be due to multiple sclerosis, but such a diagnosis was not substantiated by the laboratory investigations. Trauma " or postoperative fever ${ }^{12}$ might have precipitated multiple sclerosis.

\section{ACKNOWLEDGEMENT}

Our thanks are due to Professor N.D. Sathe, (M.D.) and Dr. R.G. Kulkarni (M.S., D.O.M.S.) for their expert guidance.

\section{REFERENCES}

1. DRIPPS, R.D. \& VANDAM, L.D. Long-term follow up of patients who received 10,098 spinal anesthetics. Failure to discover major neurological sequelae. J.A.M.A., 156: 1486 (1954).

2. Moore, D.C. \& Bridebaugh, L.D. Spinal (Subarachnoid) block. A review of 11,574 cases. J.A.M.A., 195: 907 (1966).

3. ThorséN, G. Neurological sequelae after spinal anaesthesia. Injuries due to the anaesthetic agent. Acta. Chir. Scand. Suppl. 121: 146 (1947).

4. Kennedy, F., Effron, A.S. \& Perry, G. The grave spinal cord paralyses caused by spinal anesthesia. Surg. Gyn. and Obst., 9/: 385 (1950).

5. Marinacci, A.A. \& Courville, C.G. Electromyogram in evaluation of neurological complications in spinal anesthesia. J.A.M.A., 168: 1337 (1958).

6. KRAL, V.A. Neuropsychiatric sequelae of cardiac arrest during spinal anaesthesia. One year followup of cases. Can. M.A.J., 64: 138 (1951).

7. GiLlies, J. Hypotension in anaesthesia. High spinal block. B.M.J., l: 504 (1953).

8. Discussion on the neurological sequelae of spinal anaesthesia. Proc. Roy. Soc., Med., XXX: 1007 (1937).

9. Fleiss, A.N. Multiple sclerosis appearing after spinal anaesthesia. N.Y. St. J. Med., 49: 1076 (1949).

10. Bamford, C., Sibley, W. \& Laguna, J. Anesthesia in multiple sclerosis. Can. J. Neurol. Scit., 5: 41 (1978).

11. MCAlpine, D. \& Compston, N. Some aspects of natural history of disseminated sclerosis. Quart. J. Med. N.S. 21: 135 (1952).

12. Katz, J. \& Kadis, L. Neurological disorders Demyelinating diseases. Anaesthesia and uncommon diseases: Pathophysiological and clinical correlations. Philadelphia, W.B. Saunders, 1973.

\section{RÉSUMÉ}

Les auteurs rapportent un cas d'hémiplégie avec névrite optique survenue trois heures après une rachi-anesthésie administrée pour une cure chirurgicale d'hydrocèle.

Le malade récupéra en grande partie, sous corticothérapie, mais présentait encore certains déficits neurologiques à son départ de l'hôpital, quarante-cinq jours après l'intervention. En discussion, on présente le diagnostic différentiel de ce cas. 